UDC 94 (477.83) (092):930.25

DOI: 10.24919/2519-058x.7.131616

Olha VLADYHA,

orcid.org/0000-0001-5444-7164

Ph D hab. (History), Associate Professor of Lviv Professional College of Computer Technologies and Building

(Ukraine,Lviv) olhavladyha@gmail.com

\title{
BY THE ESTUARY OF THE ARCHEOGRAFIC COMMISSION \\ OF THE NTSH (TARAS SHEVCHENKO SCIENTIFIC SOCIETY): MYKHAILO HRUSHEVSKYI'S ACTIVITY IN 1894 - 1895
}

In the article an analysis of M. Hrushevskyi's archeographic activity in the 1894-1895s has been examined. The main directions of the scientist's research (elaboration of Warsaw and Moscow archives), organizational (discussions of source study and archeographic problems at the sessions of the Historic-Philosophical section of the NTSh), and publishing (the publication of the first volume of "The Sources of the History of Ukraine-Rus'») work have been revealed. The conclusion is drawn about the significant influence of that time archeographic activity of the scientist on modernisation of the Ukrainian historical science.

Key words: M. Hrushevskyi, the Ukrainian historiography, archeography, Archeographic commission of the NTSh, "The Sources of the History of Ukraine-Rus'».

Ольга ВЛАДИГА, кандидат історичних наук, викладач історії Львівського вищзого професійного училищза комп'ютерних технологій та будівниитва (Україна, Львів) olhavladyha@gmail.com

\section{БІЛЯ ВИТОКІВ АРХЕОГРАФІЧНОЇ КОМІСІЇ НТШ: ДІЯЛЬНІСТЬ МИХАЙЛА ГРУШЕВСЬКОГО В 1894 - 1895 pp.}

У статті проаналізовано археографічну діяльність М. Грушевського протягом 1894 1895 рр. Виявлено головні напрямки пошукової (опрацювання архівів Варшави та Москви), організаиійної (обговорення джерелознавчо-археографічних проблем на засіданнях Історикофілософської секиії НТШ) та видавничої (публікація першого тому «Жерел до історії України-Руси») прачі вченого. Зроблено висновок про вагомість впливу тогочасної археографічної діяльності вченого на модернізацію української історичної науки.

Ключові слова: М. Грушевський, украӥнська історіографія, археографія, Археографічна комісія НТШ, «Жерела до історії Украӥни-Руси».

The statement of the problem. As is well-known, Mykhailo Hrushevskyi's archeographic activity in the years in Lviv was concentrated in the Archeographic commission of Taras Shevchenko Scientific Society (further on referred to as AC NTSh). Himself Volodmyr Antonovych' pupil, he had gained much experience when cooperating with the Kiev Areheographic Commission and, then, initiated the creations of such a Commission in Lviv within the frames of the Society's activity. However, before the Commission was formed in the beginning of 1896, the scientist throughout his first one and a half years after he had moved to Lviv, carried out his numerous archeographic plans in other forms. The contemporary historiography can hardly boast of knowing much of that. 
The analysis of researches. The problem of M. Hrushevskyi's archeographic activity in TSSS was repeatedly addressed to by the researchers of his life and creativity (Hyrych, 1997; Telvak, Pedych, 2016: 70-76). However, the aforementioned researchers, as well as their predecessors, focus upon his activity as the AC NTSh' chairman in 1896 - 1914. Instead, the archeographic work of the Ukrainian professor in the first years of his staying in Lviv still remains almost unknown. This fact stipulates the topicality of the present research.

The article's purpose is to comprehensively reconstruct M. Hrushevskyi's archeographic activity during $1894-1895$ on the basis of multifarious sources.

The statement of the basic material. The correspondence of the young professor with Mykola Biliashivskyi and Ivan Nechui-Levytskyi makes up the main source for the presented analysis, as well as the protocols of sessions of the Historic-Philosophical section of the NTSh, of which M. Hrushevskyi was elected director soon after his arrival in Lviv on November 16th, 1894. Actually, since then, at almost every session of the section at the initiatives of the newly elected director the problems source-study and archeographic character were discussed. Already at the aforementioned November session M. Hrushevskyi laid out a detailed enough project of expansion of the NTSh' archeographic line of activity, which fact testifies that the idea of the project had been cherished by him yet in the days of his studies in Kiev. In it, underlying the achievements of the Kiev documentary school, the scientist pronounced on by far insufficient development in detail of the Ukrainian historical science despite its an intensive advance during recent years. Such a condition, he fairly specified, appreciably depended on the lack of a compendium of the published sources. On account of that, M. Hrushevskyi accentuated that the historiographic gains of the predecessors require an attentive critical verification in that it should become a reliable base to proceed from and further to work over the existing eventual lacunas.

As an expert in the matter, M. Hrushevskyi pronounced upon the inexhaustibility of the potential of libraries and archives in what concerned the old period of Ukrainian history and, furthermore, is medieval and early modern periods. In fact, only the most popular themes, to a certain extent were then supplied with the published sources, whereas the majority of events in the Ukrainian past remained practically without any serious source support. M. Hrushevskyi exemplified his statements by such Ukrainian territories as the Belz region and Podilia, and also by the general questions of the class and economic history, formation of local administration, etc. So, the scientist underlined, it was necessary for the NTSh as the chief representative of the Ukrainian science to get down to archeographic work. By setting this task, the researcher repeats that the selection of sources should meet the requirements of «a broad understanding of the word «history» - as concerning monuments annalistic, legal, historical-literary, historical-statistical, ethnographic, of church history, educational, of everyday life, and the like» (Hrushevskyi, 1993: 151).

In M. Hrushevskyi's opinion, small collections of acts and literary monuments could be printed in the «Zapysky NTSh» («The Notes of the NTSh»). However, that obviously could not solve the problem. And the scientist initiated the foundation of a special source publishing house which he suggested to entitle as «Zherela do istorii Ukraïny-Rusi» («The Sources of the History of Ukraine-Rus'»). According to the author of the project, the edition's issues could be published regularly, twice a year, some 25 pages in size each. Appealing to the experience of Kiev Archeographic Commission, M. Hrushevskyi considered that each such issue should consist of an introductory survey up to 5 pages in size), texts of sources, and various indexes. In the content plane these issues should not be confined 
only to Galician Rus', but provide yet unpublished sources for all periods and all Ukrainian regions.

The author of the project defined the following three blocks of source monuments: 1) a collection of surveys and inventories of the Ruthenian Voivodeship of the XVI century, which then were located in the Moscow archive of the Ministry of Justice and in Warsaw's Main archive and Archive of the State Chamber; 2) the similar collection for the Belz region from the same archives; 3 ) the most ancient acts of the Podilia land kept in the archives of Warsaw, Kiev, and Lviv; 4) acts of the Belz region in the archives of the Bernardines in Lviv, and in the archives of Warsaw, Vilnius, and Moscow; 5) the acts concerning Lviv's history of the XV XVI centuries from the city and regional archives; 6) acts of the Lithuanian and Ruthenian records of civil acts for the history of the Kiev and Bratslav regions, Volhynis, and Left-bank Ukraine of the XV XVI centurus from the Moscow archive of the Ministry of Justice; 7) acts for the history of Ukraine from the XVII XVIII centuries from the archives of Moscow, which had to be the continuation of Mykola Kostomarov's archeographic publications; 8) onventories of the XVII - XVIII centuries for the history of peasantry; 9) «The General Investigation of Estates» of 1729 - 1730; 10) the Rus'-Lithuanian chronicler; 11) monuments of old Ukrainian writings of the XVI - XVII centuries, of both historical and barely literary character; 12) a collection of monuments of old Ukrainian writings, reprinted from inaccessible editions; 13) a collection of sources on the history of the Ukrainian law (Hrushevskyi, 1993: 151-153). That plan, in the scientist' consideration, outlined only the priority source requirements. Its realization was possible without considerable research efforts and financial expenses.

The realisation of such an ambitious project, as its author justly underlined, could not be the affair of separate enthusiasts. In that project M. Hrushevskyi for the first time pronounced for a necessity of establishing of a separate Archeographic Commission within the structure of the NTSh. This commission should dispose of a certain constant budget for the projects, so that the research and editorial work could be planned beforehand. Extremely interesting were the objectives that the scientific set forth for the activity of the Archeographic Commission: «... To join to the work both local and extraneous archeographic forces, to set forth archeographic tasks for elaboration [...], to take care that the works prepared for publication met the requirements concerning their content, scientific character, and language standards, to arrange archeographic excursion in order to find archeographic monuments for the history of Rus' both within and without the land, etc» (Hrushevskyi, 1993: 151-154).

His correspondence of that time testifies to the importance of this project for M. Hrushevskyi, in which the scientist informs his addressees of his archeographic plans and their coordination with the NTSh' chairmen O. Barvinskyi. So, in his letter to M. Biliashivskyi, by then the chief of archives of the former Finance administration of the Kingdom of Poland, he wrote the next: «Our local «scientific society» accepted my suggestion to start editing a collection of acts and monuments on the history of the Rus'» (Mykhailo Hrushevskyi's Correspondence, 2001: 24) The similar information can be found in his letter to I. Nechui-Levytskyi: «In the Shevchenko Society I put forward a suggestion to begin publishing the sources, which was gladly accepted» (Mykhailo Hrushevskyi's Correspondence, 1997: 45).

M. Hrushevskyi's project was optimistically apprehended by the Society's management and, as is obvious from the aforementioned letters, was confirmed in the autumn of 1894 . To it the report of the chairman of the NTSh Olexandr Barvinskyi at a general meeting on January 21 st, 1895 also testifies. Mentioning new projects which the Society started to realise, 
O. Barvinskyi noticed that «the success in the consent among the sections decided that this year «Historical sources» should be edited, which program was developed by prof. M. Hrushevskyi» ( $Z$ tovarystva / From the society, 1895a: 2).

Thus, as is evident already from the short messages on the activity of the NTSh. M. Hrushevskyi energetically, as was inherent to him, took to the realisation of the project, which he had suggested. Soon the scientist addressed to the aforementioned M. Biliashivskyi with a request to inform him whether or not in the Archive of the Royal Treasury a survey of the Ruthenian Voivodeship of the XVI century is present. His consultations with M. Biliashivskyi and his own archeographic experience pushed M. Hrushevskyi to embark on archeographic travels to Moscow and Warsaw. So, in the second half of March, 1895, the scientist worked over the funds of a Moscow archive of the Ministry of Justice, the Moscow Main archive of the Ministry for Foreign Affairs, and the Manuscript Department of Rumiantsev museum. In May of the same year he spent short-term archival searches in Warsaw. About these circumstances of his archeographic travels one can learn from the scientist's letters to M. Biliashivskyi (Mykhailo Hrushevskyi’s Correspondence, 2001: 23-37). The results of his searches M. Hrushevskyi reported at session of Historical-Philosophical sections on June 12th, 1895. Especially in detail he dwelled on his finds in Moscow Archive of internal affairs and Warsaw Archive of the Royal Treasury (From the society, 1895b: 1). The scientist contributed the substantial information on these finds into the "Zapysky NTSh» (Hrushevskyi, 1895a: 1).

The trips to Moscow and Warsaw allowed M. Hrushevskyi to restore to old and to impose new links in the milieu of archivists. Using these contacts, the scientist accomplished the copying of the manuscripts which he thought necessary, as well as their further publication in the NTSh' editions. For example, from one of the researcher's letter to M. Biliashivskyi it becomes evident that it was due to one of M. Hrushevskyi's Warsaw colleague the Ukrainian scientist found a professional copyist who made diligent copies of the manuscripts which he needed. Also, through M. Biliashivskyi, the Lviv professor asked to verify the indistinctly copied fragments of sources and their comparison with the originals (Mykhailo Hrushevskyi's Correspondence, 2001: 23-37).

A sufficiently great attention to archeographic problematics was paid by the scientist at the sessions of the the Historic-Philosophical section of the NTSh. Foe instance, protocol of 16 November 1894 testifies to the fact, that the newly elected chairman of the section presented for discussion the essay «The newly edited monuments of old Rus' writings of the XII XIII centuries», in which he dwelt on the analysis of «The legend of the death of the Rus' land» and «Metropolitan Klym's message» (CSHAU ([the] Central State Historical Archive of Ukraine). Fund (further on F.) 309. Description (D.) 1. Case (C.) 42. Sheet (Sh.) 141). At a February meeting in 1895 M. Hrushevskyi criticized V. Kotsovskyi's work «The historical-literary notes on the «Tale of Ihor's Campaign» (CSHAU in Lviv. F. 309. D.1. C. 42. Sh. 9). The protocol of 19March 1895 notifies that the director of the section informed on the valuable manuscript, found in the Ossolinski library in Lviv under the name «Metrica samboriensis» (The Sambir record of civil acts). The scientist noticed that the found manuscript was a Sambir Roman Catholic record of civil acts of the XVI century that gives a lot of interesting material concerning Catholicism and Orthodoxy relations (From the society, 1895a: 5).

At sessions the director of the Historic-Philosophical section of the NTSh also put forward essentially source study themes for discussion. So, the protocol of a session on October 24th, 1895 informs, that M. Hrushevskyi read aloud an abstract on the most ancient Lithuanian- 
Ruthenian chronicle (From the society, 1896: 1). To source study the scientist dedicated his report at the December session of the section where he presented for his colleagues' discretion his considerations concerning the text of the «Galician-Volhynian chronicle» (From the society, 1896: 1-2). This abstract later was published on the pages of the central edition of the Society. In it the scientist explained and specified a chain of fragments, which, to his mind, were not properly reflected in the edition of the chronicle (Hrushevskyi, 1895c: 1). Also, M. Hrushevskyi's small panegyric in honour of Vytovt, the grand prince of Lithuanian, mentioned in the Belorussia-Lithuanian chronicles, was purely of source study character (Hrushevskyi, 1895d).

His work on collecting of documents for the first volume of «The Sources of the History of Ukraine-Rus'» forced M. Hrushevskyi to restructure some theoretical problems of editorial archeography. So, in his letter to M. Biliashivskyi the scientist remarked: «I stick to the method of being precise in publishing the Polish acts in the original. In my opinion, to correct on modernize orthography is not good, because to such corrections, once you have stepped on this path, it is never possible to apply strong criteria» [M. Hrushevskyi's accentuation. - O. V.] (Mykhailo Hrushevskyi's Correspondence, 2001: 33). In his letters to Ivan Franko, discussing Franko's plans about editing apocryphal stories, Hrushevskyi noted this: «In our most recent conversation I forgot to agree with you upon the method of editing of apocryphal texts. Here I am of this opinion: either shortenings and titlos are to be left untouched, or all their open forms should be placed in brackets...» (Mykhailo Hrushevskyi’s Correspondence, 1997: 78).

In accordance with these theoretical instructions, M. Hrushevskyi prepared for publication the first volume of «The Sources of the History of Ukraine-Rus'». In the introduction to that edition the scientist noted a constantly increasing actuality of archeographic studios in the context of modernisation of theoretical-methodological bases of European historiography in second half of the XIX century, which was connected with the reorientation of the subject of historical science from political-dynastic problems to a wide range of social, economic, and culturological problems. M. Hrushevskyi considered such a positioning of the problems particularly important for the Ukrainian humanitarian studies (Hrushevskyi, 2003: 38). With this consideration in view and referring to his project, $M$. Hrushevskyi announced that the NTSh decided to publish archeographic materials on Ukrainian history in two source series. The first was «The Sources of the History of Ukraine-Rus'», which would contain mainly act material. The second was «Monuments of the Ukrainian alias Ruthenian language and literature», appointed for literary works.

M. Hrushevskyi separately dwelled on an explanation of the selected by him archeographic approaches to the edition of sources which qualitatively differed from the ones used by such a authoritative archeographic establishment as the Kiev Provisional Commission for consideration of ancient acts, which pupil, to an extent, the Lviv professor could be certainly considered. He suggested to publish documents completely, taking in sources of one version, irrespective of their fund belonging. In the preface the fundamental bases of rendering of the sores text was explained. The main of them it is better to present by the words of the historian himself: «to print a letter after a letter, changing nothing, even incomprehensibilities, without any corrections» (Hrushevskyi, 2003: 43). The first issue of «The Sources of the History of Ukraine-Rus'» contained surveys of Ruthenian Voivodeship of $1565-1566$. M. Hrushevskyi was convinced that they contained extremely informative material concerning social and economic development of the Ukrainian territories.

The archeographic level of Hrushevskyi's work as reflected in the first issue of «The Sources» found a favourable enough reception in the scientific criticism milieu 
(Telvak, 2008: 47-48, 52-53). Not only Ukrainian, but also Polish and Russian observers distinguished a progressive archeographic technique of the publisher who defended an exact rendering of the contents of the originals. For example, M. Dovnar-Zapolskyi specified: «From the point of view of the choice of material, one can be fully satisfied: the book includes a whole series of documents which are of utmost importance for the history of Galicia's economic life in the XVI century» (Dovnar-Zapolskyi, 1895: 146). Of particular interest were the prefaces which generalised the contributed source materials. In scientific literature their independent scientific value constantly grew, their «diligence» and «exhaustiveness» of elaboration of sources were marked out (Shcherbyna, 1896).

In his first years in Lviv M. Hrushevskyi also debuted as an archeographer of the history of Ukrainian Cossacks. On the pages of «Zapysky NTSh» he published his article «The Kiev Castellan and the Cossacks», in which he included a decree of the Seym court of 1570 on the case of the Kiev castellan Pavlo Sapieha and the Armenian merchants, that had been found out in the funds of the Moscow Archive of the Ministry of Justice (Hrushevskyi, 1895e). Another his publication of that time the researcher was dedicated the Cossacks topic, treating the activity of the known organizer of the register Cossacks Jan Oryshevskyi (Hrushevskyi, 1895f).

During his first two years of stay in Lviv M. Hrushevskyi, along with «The Sources of the History of Ukraine-Rus'», realised one more solid archeographic project which had special didactic purposes. Reading a course of the ancient history of Ukraine at Lviv university, the scientist justly considered it necessary to give into the hands of his students the base sources collected in one book. With that end in view, in 1895, on the pages of Lviv biweekly «Teacher», he published his work under the title «Excerpts from the sources on the history of Rus'». Later, this work was edited as a separate book. Explaining to readers the necessity of a complex edition of basic sources on the beginnings of Ukrainian history, M. Hrushevskyi in his introduction remarked: «I have proceeded from the conviction, that only direct acquaintance with sources on which basis the conclusions of the historical literature could be drawn, gives the clear and strong knowledge, relieves from inevitable dependence on subjectivity of this or that historical work, and gives a chance to be guided in science irrespective of differences and changes of standpoints which take place in historiography»(Hrushevskyi, 2004: 3).

The scientist explained the necessity of such an edition also by the fact that a long time Ukrainian historiography was not recognized as an independent scientific discipline, after all, there were no such source collections which would elucidate the past of the Ukrainian people as a certain complete community. The presented sources in the editions, first of all Russian and Polish, only partly could solve this problem, because they had mainly concentrated on the past of their own ethnoses and quite often incorporated Ukrainian past into their narrations (Hrushevskyi, 2004: 3). The Lviv professor considered the target audience of his collection to be not only studying youth, but also «all who inclines to a deeper and more independent study of the history of Rus' [-Ukraine]». Accounting for the unpreparedness of the readers' audience, the researcher took to branchy comments to the presented sources which was done with the purpose to lead the reader into the context of the source text origin and its information loading.

The conclusions. Thus, already in the first years of his stay in Lviv M. Hrushevskyi had already wide archeographic interests and developed the main bases of archeographic work. the Lviv professor as a successor of the traditions of Kiev Archeographic Commissions and the pupil of V. Antonovych' source study school, wonderfully understood requirements of the 
development of documentary bases of Ukrainian historical science and had necessary professional knowledge for the realisation of creative plans. Taking advantages of the constitutional advantage of Austro-Hungary, which allowed free development of Ukrainian science in the native language, the scientist, immediately after arriving in Lviv, at once suggested the plan of a large-scale archeographic searches, that aimed to result in a collection of documentary material on the key periods of Ukrainian history. Among the far-reaching consequences of that his activity was a plan of the necessary compendium of source for the reconstruction of a complete picture of the Ukrainian past and the overcoming of a chronic retardation of the domestic development of the humanities. Having headed the Historic-Philosophical section of the NTSh and - in due course - also the whole Society, the scientist, with miraculous energy, under conditions of severe shortage of necessary means, undertook the realisation of his ambitious plan, inspiring his Galician colleagues with his own industriousness. Already the first results of that work proved the correctness of his views at the prime importance of source study and anticipated the successes of archeographic activities of the Society in the end of the XIX - beginning of the XX centuries.

\section{BIBLIOGRAPHY}

Гирич, 1997 - Гирич І. Б. Організація М. С. Грушевським археографічної роботи у львівський період життя й діяльності (1894 - 1914 рр.) // Український історичний журнал. 1997. № 1. С. $72-86$.

Грушевський, 1895a - Грушевський М. Архив скарбу коронного в Варшаві. Замітка археографічна // Записки НТШ. Львів, 1895. T. VI. С. 1-4.

Грушевський, 1895b - Грушевський М. Опись подільських замків 1491 р. // Записки НТШ. Львів, 1895. T. VII. С. 1-18.

Грушевський, $1895 \mathrm{c}-$ Грушевський М. Примітки до тексту Галицько-волинської літописи // Записки НТШ. Львів, 1895. Т. VIII. С. 1-5.

Грушевський, 1895d - Грушевський М. Похвала в. кн. Витовту. Кілька уваг про склад Найдавнішої русько-литовської літописі // Записки НТШ. Львів, 1895. Т. VIII. С. 1-16.

Грушевський, $1895 \mathrm{e}$ - Грушевський М. Київський каштелян і козаки // Записки НТШ. Львів, 1895. T. VI. C. 7-9.

Грушевський, $1895 \mathrm{f}$ - Грушевський М. Надання Оришевському Копистерна та Гайсина // Записки НТШ. Львів, 1895. Т. VIII. С. 5-8.

Грушевський, 1993 - Грушевський М. Про виданє джерел до істориї українсько-руської. Записка до хв.. видїлу Наукового Товариства ім.. Шевченка // Едиційна археографія в Україні у XIX - ХХ ст. Плани, проекти, програми видань. Випуск 1. К., 1993. С. 151-154.

Грушевський, 2003 - Грушевський М. Передмова до тому 1-го «Жерел до історії УкраїниРуси» // Грушевський М. С. Твори: У 50 т. Львів: Світ, 2003. Т. 5: Серія «Історичні студії та розвідки $(1888-1896) »$. С. 38-43.

Грушевський, 2004 - Грушевський М. Виїмки з жерел до історії України-Руси до половини ХІ віку // Грушевський М.С. Твори: У 50 т. Львів: Світ, 2004. Т. 6: Серія «Історичні студії та розвідки $(1895-1900) »$. С. 3-143.

Довнар-Запольский, 1895 - Довнар-Запольский М. К истории экономического быта Галиции в XVI веке (Жерела до історії України-Руси. Під ред. М.Грушевського. Т. 1) // Журнал Министерства народного просвещения. Седьмое десятилетие. Часть CCCXV. 1895. Январь. С. 146-156.

3 товариства, 1895a - 3 товариства // Записки НТШ. Львів, 1895. Т. VI. С. 1-5.

3 товариства, 1895 b - 3 товариства // Записки НТШ. Львів, 1895. Т. VII. С. 1-2.

3 товариства, 1896 - 3 товариства // Записки НТШ. Львів, 1896. Т. IX. С. 1-2.

Листування Михайла Грушевського, 1997 - Листування Михайла Грушевського. Т. І. Київ Нью-Йорк - Париж - Львів - Торонто, 1997. 398 с.

Листування Михайла Грушевського, 2001 - Листування Михайла Грушевського. Т.II. К.; Нью-Йорк, Париж, Львів, Торонто, 2001. 412 с. 
Тельвак, 2008 - Тельвак В. Творча спадщина Михайла Грушевського в оцінках сучасників (кінець XIX - 30-ті роки XX століття). Київ-Дрогобич, 2008. 494 с.

Тельвак, Педич, 2016 - Тельвак В., Педич В. Львівська історична школа Михайла Грушевського. Львів, 2016. 440 с.

ЦДІАУЛ - Центральний державний історичний архів України у м. Львів.

Щербина, 1896 - Щербина В.: Жерела до історії України-Руси. Під ред. М. Грушевського. T. 1 // Киевская Старина. 1896. T. XLIV. C. 37-41.

\section{REFERENCES}

Hyrych, 1997 - Hyrych I. B. Orhanizatsiia M.S.Hrushevskym arkheohrafichnoi roboty u lvivskyi period zhyttia y diialnosti (1894-1914 rr.) [The organization of archeographic activity in Lviv by Mykhailo Hrushevskyi in his Lviv period of life and work (1894 1914)] // Ukraine historical magazine. 1997. № 1. Pp. 72-86. [in Ukrainian]

Hrushevskyi, 1895a - Hrushevskyi M. Arkhyv skarbu koronnoho v Varshavi. - Zamitka arkheohrafichna [The Archive of the Royal Treasury in Warsaw. - An archeographic report] // Zapysky NTSh. Lviv, 1895. V. VI. Pp. 1-4. [in Ukrainian]

Hrushevskyi, 1895b - Hrushevskyi M. Opys podilskykh zamkiv 1491 r. [Description of Podilia castles in 1491] // Zapysky NTSh. Lviv, 1895. V. VII. Pp. 1-18. [in Ukrainian]

Hrushevskyi, 1895c - Hrushevskyi M. Prymitky do tekstu Halytsko-volynskoi litopysy [Notes to the text of the Galician-Volhunian chronicle] // Zapysky NTSh. Lviv, 1895. V. VIII. Pp. 1-5. [in Ukrainian]

Hrushevskyi, 1895d - Hrushevskyi M. Pokhvala v. kn. Vytovtu. Kilka uvah pro sklad Naidavnishoi rusko-lytovskoi litopysi [A Praise to Vytovt. Some remarks on the structure of the oldest Rus'-Lithuanian chronicle] // Zapysky NTSh. Lviv, 1895. V. VIII. Pp. 1-16. [in Ukrainian]

Hrushevskyi, 1895e - Hrushevskyi M. Kyivskyi kashtelian i kozaky [The Kiev Castellan and the Cossacks] // Zapysky NTSh. Lviv, 1895. V. VI. Pp. 7-9. [in Ukrainian] [in Ukrainian]

Hrushevskyi, 1895f - Hrushevskyi M. Nadannia Oryshevskomu Kopysterna ta Haisyna [Granting Kopystern and Haisyn to Oryshevskyi] // Zapysky NTSh. Lviv, 1895. V. VIII. Pp. 5-8. [in Ukrainian]

Hrushevskyi, 1993 - Hrushevskyi M. Pro vydanie dzherel do istoryi ukrainsko-ruskoi. Zapyska do khv.. vydilu Naukovoho Tovarystva im.. Shevchenka [On the edition of the Sources of the history of Ukraine-Rus'/ A note to an organizational department of the NTSh] // Edytsiina arkheohrafiia v Ukraini u XIX-XX st. Plany, proekty, prohramy vydan [Edition archeography in Ukrainein the XIX-XX cc. Plans, projects, publication programs]. Issue 1. K., 1993. Pp. 151-154. [in Ukrainian]

Hrushevskyi, 2003 - Hrushevskyi M. Peredmova do tomu 1-ho «Zherel do istorii Ukrainy-Rusy» [Preface to Vol. I of the sources of the history of Ukraine-Rus'] // Hrushevskyi M. S. Works: In $50 \mathrm{vv.}$ Lviv: Swit, 2003. V. 5. Pp. 38-43. [in Ukrainian]

Hrushevskyi, 2004 - Hrushevskyi M. Vyimky z zherel do istorii Ukrainy-Rusy do polovyny XI viku [Excerpts from the sources of the history of Ukraine-Rus' prior to the mid XI century[ // Hrushevskyi M. S. Works: In 50 vv. Lviv: Swit, 2004. V. 6. Pp. 3-143. [in Ukrainian]

Dovnar-Zapolskyi, 1895 - Dovnar-Zapolskyi M. K istorii ekonomicheskoho byta Halytsiy v XVI veke (Zherela do istorii Ukrainy-Rusy. Pid red. M.Hrushevskoho. T.1) [On the history of economic daily life in Galicia in the XVI century (The Sources of the History of Ukraine-Rus'. Editor M. Hrushevskyi. V.1)] // Journal of Ministry of People's Education. The seventh decade. Part CCCXV. 1895. January. P. 146-156. [in Russian]

From the society, 1895a - Z tovarystva [From the society] // Zapysky NTSh. Lviv, 1895. V. VI. P. $1-5$. [in Ukrainian]

From the society, $1895 \mathrm{~b}-\mathrm{Z}$ tovarystva [From the society] // Zapysky NTSh. Lviv, 1895. V. VII. P. 1-2. [in Ukrainian]

From the society, $1896-\mathrm{Z}$ tovarystva [From the society] // Zapysky NTSh. Lviv, 1896. V. IX. P. 1-2. [in Ukrainian]

Correspondence of Mykhailo Hrushevskyi, 1997 - Lystuvannia Mykhaila Hrushevskoho [Correspondence of Mykhailo Hrushevskyi]. V. I. Kiev - New York - Paris-Lviv-Toronto, 1997. 398 p. [in Ukrainian]

Correspondence of Mykhailo Hrushevskyi, 2001 - Lystuvannia Mykhaila Hrushevskoho [Correspondence of Mykhailo Hrushevskyi]. V. II. Kiev - New York - Paris- Lviv- Toronto, 2001. 412 p. [in Ukrainian] 
Telvak, 2008 - Telvak V. Tvorcha spadshchyna Mykhaila Hrushevskoho v otsinkakh suchasnykiv (kinets XIX - 30-ti roky XX stolittia) [Creative Heritage of Mykhailo Hrushevskyi in judgements of his contemporaries (end XIX c. - 1930s)]. Kiev-Drohobych, 2008. 494 p. [in Ukrainian]

Telvak, Pedych, 2016 - Telvak V., Pedych V. Lvivska istorychna shkola Mykhaila Hrushevskoho [Lviv historical school of Mykhailo Hrushevskyi]. Lviv, 2016. 440 p. [in Ukrainian]

CDIAUL - Central State Historical Archive of Ukraine in Lviv.

Shcherbyna, 1896 - Shcherbyna V.: Zherela do istorii Ukrainy-Rusy. Pid red. M. Hrushevskoho. T.1 [The Sources of the History of Ukraine-Rus'. Editor M. Hrushevskyi. V.1] // Kievskaia Starina. 1896. V. XLIV. Pp. 37-41. [in Russian]

Стаття надійшла до редакиії 8.04.2018 р. 